\title{
The Effect of Labor Flexibility on Firm Performance in Indonesian Telecommunication Industry
}

\author{
Nugraha Natasaputra, Ratih Dyah Kusumastuti \\ University of Indonesia, Depok, West Java 16424, Indonesia
}

\begin{tabular}{|c|c|}
\hline ARTICLE INFO & A B S T R A C T \\
\hline $\begin{array}{l}\text { Keywords: } \\
\text { Labor Flexibility, } \\
\text { Business Environment, } \\
\text { Business Strategy, } \\
\text { Firm Performance, } \\
\text { Telecommunication Industry }\end{array}$ & $\begin{array}{l}\text { The purpose of this study is to analyze the influence of the dynamic } \\
\text { business environment, the type of the company's business strategy, } \\
\text { external labor flexibility, and internal labor flexibility on the firm } \\
\text { performance. The unit of analysis in this study is the company, i.e. the } \\
\text { companies in the telecommunications sector in Indonesia. This study } \\
\text { uses primary data, through the distribution of questionnaires. Statistical } \\
\text { technique used is partial least squares structural equation method } \\
\text { (PLS-SEM). The findings suggest that the implementation of labor } \\
\text { flexibility is important for the company to compete more efficiently } \\
\text { in the market, but the implementation should match the company's } \\
\text { goal. Moreover, to achive the best firm performance, the company may } \\
\text { implement both types of labor flexibility, however the implementation } \\
\text { of internal labor flexibility should have higher priority. }\end{array}$ \\
\hline
\end{tabular}

(C) 2014 IRJBS, All rights reserved.

Corresponding author:

ratih.dyah@ui.ac.id

\section{INTRODUCTION}

The Indonesian Telecommunications Industry has a high level of competition. Until the year of 2014, Indonesia has eight telecommunication companies and dozens of companies associated with the telecommunications industry. These companies operate and compete in the market with a penetration rate of mobile subscribers of $125 \%$ by the end of 2013 (GSMA Intelligence, 2014). The telecommunication companies must continue to innovate both in product/service creation and in the implementation of marketing strategies.

In addition to the market conditions, changes in technology is also happening very frequently in the industry. For instance, the change of technology in the mobile phone business, ranging from $2 \mathrm{G}$ (second generation), known in the era of the late 90 's, followed by the release of $3 \mathrm{G}$ technology (third generation) in early $2000 \mathrm{~s}$, and the latest is 
the presence of $4 \mathrm{G}$ (fourth generation) globally, which starts to be commercialized around the year 2010 (GSMA intelligence, 2014). To be able to compete in this highly competitive condition, Indonesian telecommunication companies must spend a substantial investment in technology development, though the return on investment for the previous technology has not reached the maximum level.

According to the resource-based view theory (RBV), resources, capabilities, and core competencies that are valuable, rare, inimitable, and non-substitutable, generate sustained competitive advantages (Barney, 1991). However, environmental uncertainty in the supply of finance and customers can erode resource value, resource rareness and competitive advantage resulting in weaker future organization performance. The achievement of competitive advantage is a dynamic bargain, meaning that some firms in some circumstances are able to achieve sustained competitive advantage, while some firms in some industries achieving only temporary competitive advantage. O'Shannassy (2008) argues that not all of the elements of environmental uncertainty act in the same direction on strategic resources, competitive advantage and organization performance. Industrial Organization theory (I/O) further explains that the rate of return on average can be obtained when the company is able to effectively learn the external environment as a basis to identify the attractive industry, and then implement the appropriate strategy (Ireland, Hoskisson \& Hitt, 2013).

The company must have an effective strategy, which integrates the ability to predict the future as well as to react to unexpected events (Mintzberg et al., 1998). Companies that develop and/or acquire internal expertise to implement their strategy (as required by the external environment) is likely to succeed, while those that do not do so tend to experience failure (Ireland, Hoskisson \& Hitt, 2013).
In order to develop the organization's capability, every company needs to consider the four key-success-factors, namely human resources (HR), work processes, organizational structures, and technology (Davenport, 1999). The implementations of HR and organizational strategies are important to the successful implementation of the company's business strategy (Davenport, 1999, Boudreau, 2007). The organization must also change in order to respond to the market demand which is determined by changes in the environment. Therefore, the need for flexibility (in general) and the flexibility of human resources (in particular) will be higher in a dynamic business environment (Grant, 1996 in Bhattacharya, 2000).

The flexibility in the application of HR policies and systems of work, will affect the effectiveness of the company's human resources system, which in turn will affect the commitment, performance and productivity of employees, and ultimately can affect the performance of the company (Tracey, 2013, Whitener, 2001)

There are two dimension of HR flexibility, namely flexibility of labor source and flexibility of labor coordination (Wright and Snell, 1998). The researchers agree that based on the facts, practices and HR policies should be related to each other (Baird and Meshoulam, 1988; Becker and Gerhart, 1996; Huselid, 1995). It means that the effect of HR practices on firm performance can vary greatly depending on the implementation of other types of practice.

There are still some gaps in labor flexibility that remain unexplained in previous studies. The purpose of labor flexibility is to reduce operating costs and/or increase the ability of the company's flexibility (Sanchez et al., 2007), however some literature discusses the problems in its application. Problems in external labor flexibility include quality and productivity of the contract employee, conflicts between contract and non-contract 
Table 1. Dimension of Labor Flexibility

\begin{tabular}{lll}
\hline \multirow{2}{*}{ Type of flexibility } & \multicolumn{2}{c}{ Strategy focus } \\
\cline { 2 - 3 } & \multicolumn{1}{c}{ External } & \multicolumn{1}{c}{ Internal } \\
\hline $\begin{array}{l}\text { Volume/working time } \\
\text { (Quantity) }\end{array}$ & $\begin{array}{l}\text { Numerical flexibility } \\
\text { (e.g.: contract worker, etc.) }\end{array}$ & $\begin{array}{l}\text { Working time flexibility } \\
\text { (e.g.: Flexitime, overtime, etc.) }\end{array}$ \\
\hline $\begin{array}{l}\text { Working organization } \\
\text { (Quality) }\end{array}$ & $\begin{array}{l}\text { Outsourcing/Externalization } \\
\text { (e.g.: consultant services, etc.) }\end{array}$ & $\begin{array}{l}\text { Functional Flexibility } \\
\text { (e.g.: multiskilling, job sharing, } \\
\text { etc.) }\end{array}$ \\
\hline
\end{tabular}

Source: Grenier, Gile \& Belanger, 1997

employees, low commitment of the contract employees, and conflicts between management in the companies with company's unions. The implementation of internal labor flexibility also has some potential problems, although it is not as much as external labor flexibility. Therefore, instead of improving the company's performance, labor flexibility may also weaken the company's ability to implement its competitive strategy.

According to Blyton and Morris (1992), labor flexibility is defined as the ability of management to distinguish the use of labor (in terms of number, qualification and time) in a company to face the fluctuations and changes in the demand level and pattern. Grenier, Gile \& Belanger (1997) classifies labor flexibility based on the type of flexibility and the strategy focus of flexibility. The type of flexibility is classified based on the workforce/ working time and the working organization, while the strategy focus is classified in terms of internal and external. Table 1 describes four dimensions of labor flexibility.

This study discusses the application of labor flexibility (HR practices related to the selection and use of labor) and its relation to firm performance, especially in the companies in the Telecommunications sector in Indonesia. The types of companies included in this research are providers of telecommunications services and infrastructure, as well telecommunications equipment and application (content). This study aims to analyze the influence of a dynamic business environment and the type of business strategy on the implementation of labor flexibility and its impact on the performance of the Indonesian telecommunication companies. We hope to gain insights on the application of labor flexibility in the telecommunication industry, and its influence in achieving the company's goal.

The remaining of the paper is organized as follows. Section 2 presents the proposed conceptual model, hypothesis and research methodology, followed by results and discussion in Section 3, managerial implications in Section 4, and conclusion and recommendations in Section 5.

\section{METHODS}

The purpose of this study is to analyze the effect of the dynamic business environment and the type of business strategy on the firm performance through the mediation of external and internal labor flexibilities. The conceptual model has two independent variables, which are dynamic business environment and the type of business strategy, and then three dependent variables, which are external labor flexibility, internal labor flexibility and firm performance (see Figure 1).

The company must be able to adapt to changing business environment, therefore companies need an effective strategy, including flexibility. HR flexibility plays an important role in increasing the company's capacity to operate effectively in a competitive environment dynamism (Dess and Beard, 1984; Simerly and Li, 2000, in Tracey, 2013). 


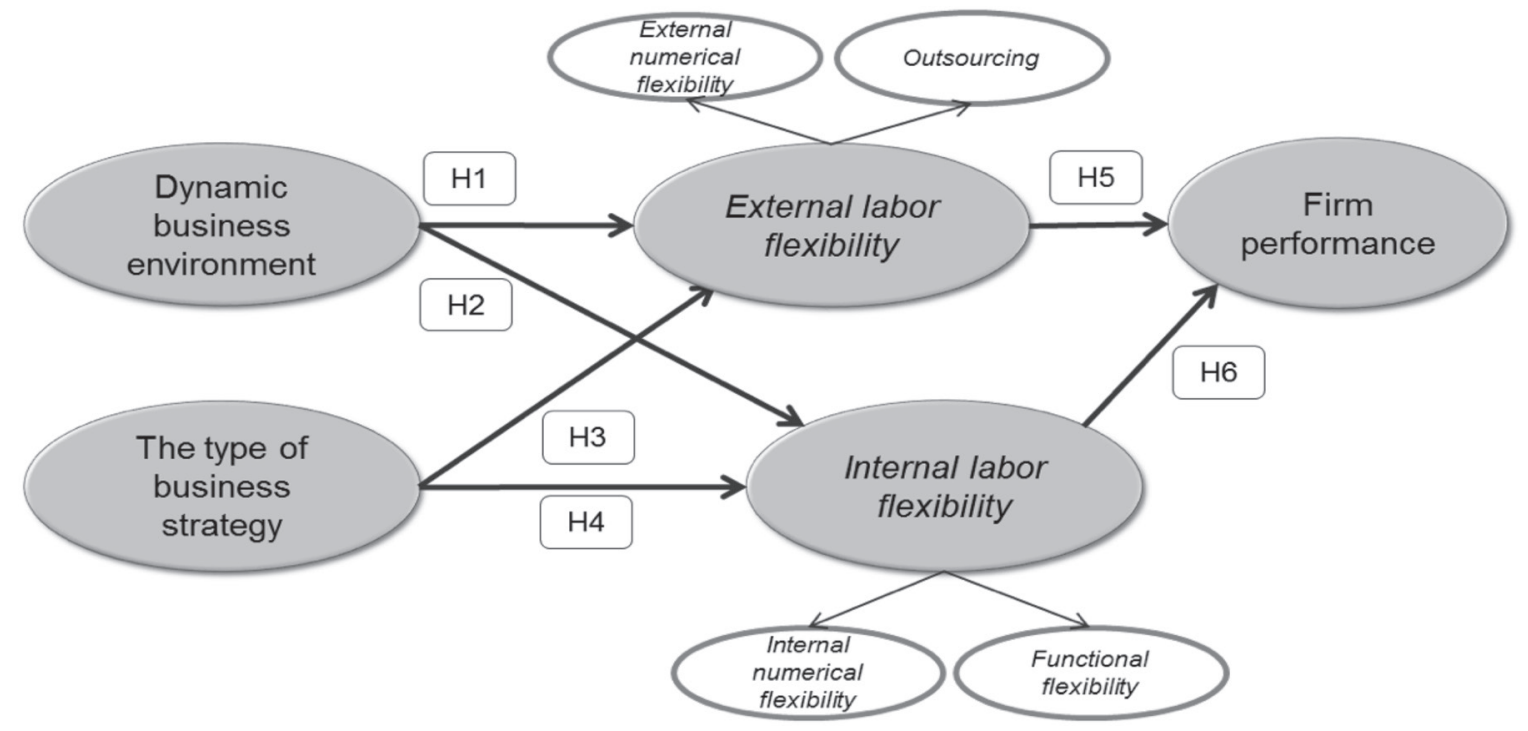

Figure 1. The proposed conceptual model

Previous research discusses the influence of a dynamic business environment on labor flexibility, and some of them conclude that due to dynamic business environment, the benefit of outsourcing implementation is increasing (Giley and Rasheed, 2000). Other studies have also suggested that a dynamic business environment is significantly associated with the outsourcing implementation (Sanchez et al., 2007). Therefore, we hypothesize that:

Hypothesis 1: Dynamic business environment has a significant influence on the external labor flexibility.

Hypothesis 2: Dynamic business environment has a significant influence on the internal labor flexibility.

Michie and Sheehan (2001) explain that the company's business performance will increase when there is a fit between business strategy and human resources. All the policies and practices of human resources should be consistent with the corporate strategy (Miles and Snow, 1978). Furthermore, Schuler and Jackson (1987) in Michie and Sheehan (2001), link the three types of competitive strategy (Porter, 1985) with the labor behavior, and human resource practices that must be implemented by the company.

Several studies conclude that out of the three types of generic strategies, the cost leadership strategy is the one that has significant influence on the intensiveness of outsourcing implementation (Sanchez et al., 2007). Moreover, cost leadership strategy increase the positive influence of outsourcing (of non-core activities) to firm performance. Therefore, our third hypothesis is:

Hypothesis 3: The type of business strategy has a significant influence on external labor flexibility.

Berg (2008) finds that the implementation of working time flexibility brings benefits to the employer (company), including effective coordination between demand and supply of labor, and lower operational costs due to the decrease in total number of overtime hours worked. In addition, the flexibility also allows cost saving in terms of elimination of termination of employment cost due to variations in the business cycle, and the absence of the training costs for new employees (Ramendran et al., 2013). 
Functional flexibility is a collaborative approach between the employee and the company, which refers to the efficiency and effectiveness of the company's commitment to achieve the company's goal (Ramendran et al., 2013). Cavagnoli (2008) in Ramendran (2013), further defines functional flexibility as the company's ability to efficiently utilize human resources in a variety of tasks and occupations by providing a safe and challenging environment.

Based on the above explanation, the implementation of internal labor flexibility can be described as human resource policy that supports successful implementation of the company's business strategy by reducing labor cost or by increasing the effectiveness of labor utilization. Therefore the hypothesis is as follows:

Hypothesis 4: Type of business strategy has a significant influence on internal labor flexibility.

Giley and Rasheed (2000) focus on the external labor flexibility through outsourcing activities. They conclude that there are negative effects of the activity, proven by the decreasing performance of several companies in the United States due to the implementation of outsourcing in activities which are close to the companies' primary activities. However, Sanchez et al. (2007) conclude that the implementation of external labor flexibility (both outsourcing and external numerical flexibility) have no correlation with the firm performance.

In a different perspective, Laugen et al. (2004a) in Sanchez et al. (2007) finds a relationship between the best outsourcing implementation and the company's high performance. Further research by Tjandraningsih (2008) finds that European companies confirm that the purpose behind the implementation of external labor flexibility is to compete more efficiently in the market, so that the company can improve its position or be able to survive. Therefore, the following hypothesis is proposed.
Hypothesis 5: External labor flexibility has a significant influence on firm performance.

Valverde (2000) reveal that the annualized hour (type of internal labor flexibility) does not have a significant correlation to firm performance. However, Sanchez et al. (2007) explains that internal labor flexibility (both Functional and internal numerical flexibility) was positively related to firm performance. Therefore the hypothesis that can be taken are as follows;

Hypothesis 6: Internal labor flexibility has a significant influence on firm performance.

The primary data used in this research is obtained through the distribution of questionnaires to the respondents by using email. All measurement variables used in this study have been used in previous studies and the period of data collection is approximately 4 weeks. Furthermore, the unit of analysis of this research is the company, because the determination of the type of business strategy and human resource policies are developed at the company level.

The research object is companies in the telecommunications sector in Indonesia. The sample companies in this research can be classified into: Telecommunications equipment provider (such as towers, fiber optic cable, telecommunications radio, satellite, and device), telecommunication service/product and/or network provider, and application and content provider. Currently, the number of companies in the telecommunications sector is approximately 102 throughout Indonesia. We use purposive sampling method (the sample is determined by the researcher), and the respondents are managers who work for the companies in the telecommunications sector. Variables and indicators are presented in Table 2.

In the measurement of the dynamic business environment, type of the business strategy, internal 
Table 2. Variables and indicators

\begin{tabular}{|c|c|c|}
\hline Variables & Dimensions & Indicators \\
\hline \multirow{3}{*}{$\begin{array}{l}\text { Dynamic } \\
\text { business } \\
\text { environment }\end{array}$} & & The speed of technological change in the industry \\
\hline & & The speed of obsolescence of products and services in the industry \\
\hline & & The level of difficulty to predict competitors' actions \\
\hline \multirow{12}{*}{$\begin{array}{l}\text { Type of business } \\
\text { strategy }\end{array}$} & \multirow{4}{*}{$\begin{array}{l}\text { Cost leadership } \\
\text { strategy }\end{array}$} & The company's focus on cost minimization \\
\hline & & The company frequently cuts the price of products and/or services \\
\hline & & The company analyzes the cost changes to determine the cause \\
\hline & & The company develops/enhances the existing products \\
\hline & \multirow{4}{*}{$\begin{array}{l}\text { Differentiation } \\
\text { strategy }\end{array}$} & The company made innovations in marketing techniques and methods \\
\hline & & $\begin{array}{l}\text { Quality and innovation make the company's products different from } \\
\text { the competitors' }\end{array}$ \\
\hline & & The company has full control of distribution channels \\
\hline & & The company does massive advertising activities. \\
\hline & \multirow[t]{4}{*}{ Focus strategy } & The company provides services in a particular target area \\
\hline & & The company is able to make special products \\
\hline & & The company's products are in the high-end market segment \\
\hline & & The company is focusing on customer service \\
\hline \multirow{8}{*}{$\begin{array}{l}\text { External labor } \\
\text { flexibility }\end{array}$} & \multirow{4}{*}{$\begin{array}{l}\text { External } \\
\text { numerical } \\
\text { flexibility }\end{array}$} & The company uses temporary contract employees \\
\hline & & The company uses a contract employee for a certain time period \\
\hline & & The company uses part-time employees \\
\hline & & The company uses on-call employees \\
\hline & \multirow[t]{4}{*}{ Outsourcing } & The company outsource supporting activities \\
\hline & & The company outsource technology-related activities \\
\hline & & The company outsource operational activities \\
\hline & & $\begin{array}{l}\text { The company outsource marketing, sales and customer service } \\
\text { activities }\end{array}$ \\
\hline \multirow{8}{*}{$\begin{array}{l}\text { Internal labor } \\
\text { flexibility }\end{array}$} & \multirow{4}{*}{$\begin{array}{l}\text { Internal } \\
\text { numerical } \\
\text { flexibility }\end{array}$} & The company implements overtime \\
\hline & & The company operates a policy of working time flexibility \\
\hline & & The company has a policy of workload reduction \\
\hline & & The company applies work distribution \\
\hline & \multirow{4}{*}{$\begin{array}{l}\text { Functional } \\
\text { flexibility }\end{array}$} & The employees have a variety of skills that can be used for various jobs \\
\hline & & $\begin{array}{l}\text { The company is able to meet the demand for new skills through } \\
\text { training program or internal recruitment }\end{array}$ \\
\hline & & The company may assign an employee for a new job when needed \\
\hline & & Each employee is encouraged to contribute for the company's success \\
\hline \multirow[t]{5}{*}{ Performance } & & Growth in operating revenues \\
\hline & & Operating profit margin \\
\hline & & Operating profit per employee \\
\hline & & The company's market share compared to its competitors' \\
\hline & & The company's overall performance and success \\
\hline
\end{tabular}


labor flexibility and firm performance variables we use a 6 (six) Likert scale, with answers ranging from strongly disagree to strongly agree. In order to measure the external numerical flexibility and outsourcing, on the other hand, we provide 2 options of answers: 1 (one) for "NO" and two (2) for "YES".

The data processing is conducted in several stages. Firstly, a pretest is conducted with 20 respondents, then the collected data is processed using SPSS. The pre-test results is used to improve the quality of the questionnaire that will be used for data collection. Data processing using cluster analysis is then conducted for the purpose of classifying all respondents based on the business strategy. Partial least square structural equation method (PLS-SEM) is then used to analyze the data as it can be used on any kind of data scale (nominal, ordinal, interval and ratio) and has more flexible assumption terms (Yamin and Kurniawan, 2011), in addition, PLS-SEM can be used to estimate the path model of a small sample (Chin and Newsteed 1999 in Yamin and Kurniawan, 2011). The number of samples that can be used in PLS is at least 30 to 100 samples (Yamin and Kurniawan, 2011). We use Smart PLS 2.0 M3 to process the data.

\section{RESULTS AND DISCUSSION}

Out of 91 questionnaires sent by email, 67 questionnaires are returned. However, only 62 questionnaires are considered valid to be used and processed in further stages of the research. The respondent profile shows that the majority of respondents are employees of the company which has been established for more than 10 years, with a headcount of more than 2,000 people, and they have been with the company for more than 5 years. Furthermore, the position of the respondents in the company is starting from the first line manager up to the top managers, with an experience of 1 to 3 years in that particular position.

Reliability and validity of the constructs are carried out using SPSS 17.0. The result shows that the
Cronbach's alpha is 0.866 , meaning that the constructs are reliable. The results also show that almost all indicators measuring the latent variable are valid. There are only a few indicators that have factor loading below 0.5 , but they are still used, because they are needed to explain the related variables.

Cluster analysis is conducted to identify the company's strategy. A four-cluster analysis groups the respondents into 4 clusters indicating different types of strategy, namely cost leadership, differentiation, focus strategies, and stuck in the middle. The results show that cluster 1 consists of 6 respondents which strategy is stuck in the middle, cluster 2 comprising 10 respondents with differentiation strategy, cluster 3 consists of 26 respondents with cost leadership strategy, and cluster 4 comprising 20 respondents with focus strategy. Because the sample size in this research is only 62 , the requirement of covariance-based SEM models can not be fulfilled to test the model. The examination of hypothesis on the structural model is done by using the bootstrapping process to get the t-test value and understanding the path coefficient between variables. The results show that out of 6 existing hypothesis, 3 hypothesis are supported by the data, namely Hypothesis 2,4 , and 6 . The three other hypothesis are not supported by the data, they are Hypothesis 1, 3, and 5. The summary of hypothesis testing is presented in Figure 2.

From the results in Figure 2, it can be concluded that the dynamic business environment variable has a significant path coefficient to internal labor flexibility, however it does not have a significant effect on the external labor flexibility. Types of business strategy variable also has a significant path coefficient to internal labor flexibility, but does not have a significant influence to the external labor flexibility. Furthermore, the internal labor flexibility has a significant path coefficient to firm performance, while external labor flexibility does not. 


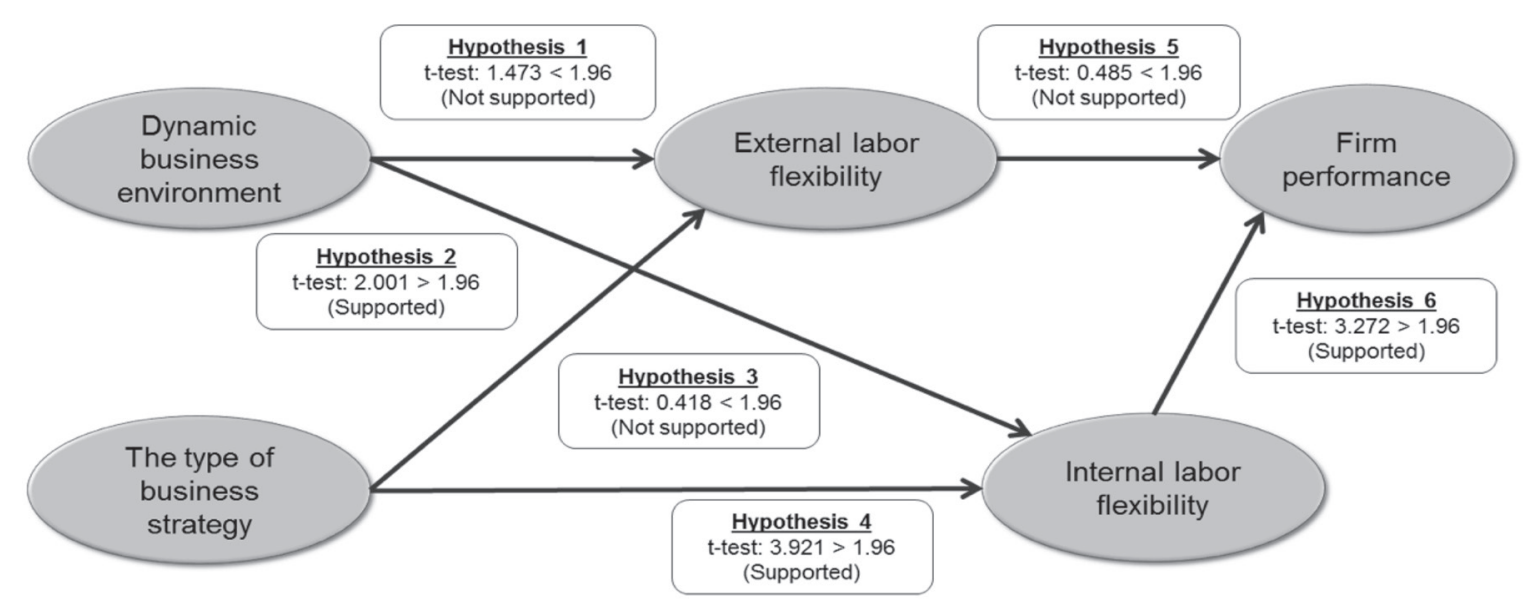

Figure 2. Hypothesis examination result on structural model

The results also show that the coefficient of determination $\left(R^{2}\right)$ of external labor flexibility variable is 0.084 , meaning that the independent variables (dynamic business environment and the type of business strategy) have a weak influence on external labor flexibility. Furthermore, the internal labor flexibility has an $R^{2}$ value of 0.395 , which means that the dynamic business environment variable and the type of business strategy have a moderate influence on internal labor flexibilty. Finally, the value of $R^{2}$ of the firm performance variable is 0.594 , which means that external labor flexibility and internal labor flexibility have a moderate effect on firm performance.

The last stage is the validation of the model as a whole, which is measured using the goodness of fit (GoF). The multiplication of the square root of the average value of the communalities index by average value of $R^{2}$, generates the value 0.514 . Therefore, the GoF for this model qualifies as large GoF, or the overall performance (a combination of the measurement model and the structural model) of the research model is valid.

Results of statistical tests show that Hypothesis 1 is not supported by the data or the influence of dynamic business environment is not significant to external labor flexibility. These results indicate that a change in the dynamic business environment can only change a decision to use outsourcing to the work function related with the technology and the operational activities, but does not distinguish among the work functions of marketing, sales and customer service. In terms of contract employee that will be use by the company, a change in the business environment does not distinguish between the decision to use a temporary contract employees, fixed term employees, or part-time employees.

From these results, it can be concluded that there is a phenomenon in the Indonesian telecommunication companies, which is the shifting of the business focus, i.e. technology was a core business in the past, but nowadays companies have begun switching their focus to non-core business. As an example, telecommunication provider companies starting to outsource its management in mobile telecommunications tower, changing their focus by providing the best customer experience, so the work functions associated with the customers (such as marketing, sales and customer service) are treated as core business function that must be managed properly by the companies, and are then used as their competitive advantage. 
The results also indicate that Hypothesis 2 is supported by data. The results are reasonable, because most of the respondents in this research are employees of the telecommunication companies that have been established for a long time, and the respondents have a relatively long working experience within the company. Therefore, the strong corporate culture is already attached to the employees, and the impact of this condition is that they tend to resist the external labor, and think that the development of internal labor should be the main focus to adapt to the changing business environment.

Furthermore, the results also show that Hypothesis 3 is not supported by data, which means that the influence of the type of business strategy is not significant on the external labor flexibility. Different types of business strategies that have been implemented by company do not specifically distinguish the type of external labor flexibility practice in the company, either outsourcing or using the temporary/fixed contract employees. These findings indicate that the implementation of external labor flexibility is not based on the strategy of the company. Research by Tjandraningsih (2008) also indicates that since labor flexibility was introduced to Indonesia through the enactment of the Act no.13 of 2003, many outsourcing companies in Indonesia are owned and managed by people who have power and a strong influence in the community. With their power and influence, they push the user to use their outsourcing services. This becomes one of the causes of the missing link between the business strategy of the company and the manpower criteria (or quality of the outsourcing) required by the company.

It can also be seen that Hypothesis 4 is supported by data, meaning that type of business strategy determines the type of internal labor flexibility implemented by the companies. Telecommunication companies with a focus strategy choose to use functional flexibility to drive corporate performance, because a company with this strategy requires a workforce with specialized skills to be able to produce a different service than the competitors. While telecom companies with a differentiation strategy, choosing to use internal numerical flexibility, as it is expected to provide flexibility to the employees to choose working time, can increase creativity, innovation, and increase employee commitment leading to good company's performance.

For companies with cost leadership strategy, the effect on the internal numerical flexibility is not as significant as the other strategies, or the development of internal labor skills is not a priority as the main focus is finding the best way to reduce costs. In general, companies in this group choose to use outsourced labor at a low cost and lowwage cemployess for their operational activities.

The findings also indicate that Hypothesis 5 is not supported by data. This result is consistent with several previous researches (such as Valverde (2000), Gilley \& Rasheed (2000), and Sanchez at al. (2007) which concluded that the implementation of the external labour flexibility has insignificant effect on firm performance). This is due to problems in the use of external labor, such us problems in quality and productivity, the potential conflict with the internal labor, and also the lack of commitment. Furthermore, the employment system in Indonesia considers labor force as a commodity instead of an instrument of production, and therefore they are not protected by the authorized institution to avoid the exploitation practices. This condition affects the productivity of labor and ultimately the performance of the company.

It can also be seen that Hypothesis 6 is supported by data. These results are consistent with several previous research (such us Sanchez et al. (2007), which concluded that the internal labor flexibility (both functional and internal numerical flexibility have a positive impact to firm performance). In order to help employees to be able to perform 
in different tasks and functions, the company need to provide trainings and job rotations. The implementation of these practices will result in benefits for both employees and the company. From the employees' perspective, they can improve the individual capability and performance, while for the company, they have employees who posses multi-skills that are ready to face rapid changes in the business situation.

\section{MANAGERIAL IMPLICATIONS}

The results can be used as a guidance for decision making related to human resources strategy to respond to changes in business environment, and to support the chosen business strategy implementation in achieving the targeted company performance.

The motivation behind labor flexibility implementation is mainly the need to compete more efficiently in the market, either to survive or to improve the market positioning (Tjandraningsih, 2008). However, the management team must be able to formulate the strategy to achieve vision and mission as it plays an important role in determining the company's focus and objectives. Clear focus and objectives help the company to synchronize its business strategy with operational strategy so that the developed policy can support the strategy effectively.

Furthermore, the implementation of labor flexibility needs to be tailored according to what the company needs, which is to anticipate changes in the business environment and also to support the implementation of the company's business strategy. In terms of the problem in determining the type of labor flexibility, companies can implement both types of flexibility, however prioritizing the implementation of internal labor flexibility will have a more significant effect on the firm performance.

In the case whereby the company has low-skilled contract workers, the company should give proper labor rights and avoid exploitation, so that the gap between permanent and contract workers is not that high and contract workers' motivation is maintained. In other case, in which the company has foreign workers/consultants, the company should ensure that the transfer of knowledge takes place so that the internal labor's compentency is increased that leads to better company performance.

\section{CONCLUSION}

The purpose of this research is to analyze the influence of dynamic business environment, the type of business strategy against labor flexibility, and then to analyze which type of labor flexibility that has an influence on the firm performance. Based on the results, it can be concluded that dynamic changes in the business environment and the selection of the type of strategy only affect the internal labor flexibility. Moreover, from the types of labor flexibility, only internal labor flexibility that has an influence on the firm performance.

Firstly, the result shows that the telecommunications company in Indonesia, has not fully practiced flexibility in the process of getting the labor force. The use of external labor is not intended to adjust the company's competition ability to adapt to changing business environment. Furthermore, they do not distinguish between outsourcing and contract employees when there is a change in the business environment. However, dynamic business environment has a significant positive effect to the internal labor flexibility. Changes in the business environment cause changes in the implementation of functional flexibility, and the number of hours worked by the employees. This shows that most of the Indonesian telecommunications companies prioritize the development of internal labor rather than using external or contract employees.

Secondly, the findings also suggest that any type of business strategy tend to be in common in deciding to implement the external labor flexibility (both 
outsourcing and contract employees). However, the findings indicate that there is a significant effect of the type of business strategy on internal labor flexibility. Telecommunication companies with a focus strategy choose to use functional flexibility to drive firm performance, while those with a differentiation strategy implement internal flexibility to provide working time flexibility, with the aim for more creative and innovative employees to drive the best performance of the company. Unlike the other two groups, companies with cost leadership strategy find ways to reduce costs, and therefore choose to use outsourced labor at low cost, and low wage employees.

Thirdly, the findings support previous research results, and assert that the problems in the external labor lead to insignificant effect of the implementation of external labor flexibility on firm performance, while the implementation of internal labor flexibility has a significant influence on the performance. Increased competence and expertise through the improvement of the education level, the provision of training, while also providing the working time flexibility and/or work location flexibility will cause employees to have a variety of skills and gaining the convenience to work as well as motivation and loyalty, which in turn will increase productivity and performance of the company.

The results prove that in Indonesian telecommunication companies, the implementation of external labor flexibility has no significant effect on the firm performance, and the implementation of internal labor flexibility has a significant influence on the firm performance. These results are similar to results of previous research conducted in European countries and America. However, further research is still needed to be done to study the implementation on labor flexibility in other industries in Indonesia, and the relationships between labor flexibility policy and other HR policies towards the achievement of the company's performance.

REFERENCES

Baird, L. \& Meshoulam, I. (1988). Managing two fits of strategic human resource management. Academy of Management Review, 13, 116-128.

Barney, J. (1991). Firm resources and sustained competitive advantage. Journal of Management, Vol. 17 No. 1, pp. 99-110.

Becker, B. \& Gerhart, B. (1996). The impact of human resource management on organizational performance: progress and prospects. Academy of Management Journal, 39, 779-801

Berg, P. (2008). Working time flexibility in the German employment relations system: implications for Germany and lessons for the United States. Journal of Industrial Relations, 15(2), 133-150.

Bhattacharya, M. (2000). Human Resource flexibility and firm performance. The Graduate School Syracuse University. UMI number: 9989370. August 2000.

Blyton, P. \& Morris, J. (1992). HRM and the limits of flexibility. in Blyton, P. and Turnbull, J. (Eds) (1992), Reassessing Human Resource Management, Sage Publications, London, pp. 116-30

Boudreau, J.W., \& Ramstad, P.M. (2007). Beyond HR. The New Science of Human Capital. Harvard Business School Press. Boston, Massachusetts.

Davenport, T.O. (1999). Human Capital, Why it and why people invest it. Jossey-Bass Publisher, San Francisco.

Gilley, K.M. \& Rasheed, A. (2000). Making more by doing less : An Analysis of Outsourcing and its effect on firm performance. Journal of Management 2000, Vol.26, No.4, 763-790.

Grenier, J. \& Gile, A. \& Belanger, J. (1997). Internal versus external labour flexibility, A two-plant comparison in Canadian Manufacturing. Relation Industrielles; Fall 1997; 52, 4; ProQuest pg.683. 
GSMAIntelligence (2014). https://gsmaintelligence.com/markets/1531/dashboard/

Huselid, M.A. (1995). The impact of human resource management practices on turnover, productivity, and corporate financial performance. Academy of Management Journal, 38, 635-672.

Ireland, R.D., Hoskisson, R.E., \& Hitt, M.A. (10 $0^{\text {th }}$ ed) (2013). The Management of Strategy. South-Western, Cengage Learning.

Michie, J. \& Sheehan, M. (2001). Business Strategy, Human Resources, Labour Market Flexibility and Competitive Advantage. International Journal of Human Resource Management, 16 (3), 445-464.

Miles, R.E., Snow, C.C., Meyer, A.D. \& Coleman Jr., H.J. (1978). Organizational Strategy, Structure, and Process. The Academy of Management Review, Vol. 3, No. 3 (Jul., 1978), pp. 546-562.

Mintzberg H., Ahlstrand, B. \& Lampel, J. (1998). Strategy Safari. A Guided Tour through the wilds of Strategic Management. The Free Press.

O’Shannassy, T. (2008). Sustainable competitive advantage or temporary competitive advantage, Improving understanding of an important strategy construct. Journal of Strategy and Management Vol. 1 No. 2, 2008. pp. 168-180.

Porter, M.E. (1985). Competitive Advantage. Creating and sustaining superior performance. The Free Press

Ramendran, SPR. C., Raman, G., Mohamed, R.K.M.H., Beleya, P., Nodeson, Suresh (2013). Organization Flexibility and its implication on employee productivity. Institute of Interdisciplinary Business Research. February 2013 Vol 4, No 10.

Sanchez, A.M., Vela, M.J., Luis, P. \& Perez, M. (2007). Managerial perceptions of workplace flexibility and firm performance. International Journal of Operations \& Production Management.Vol. 27 No. 7, 2007 pp. 714-734

Tjandraningsih, I. \& Nugroho H. (2008). The flexibility regime and organised labour In indonesia. University of Tasmania.

Tracey J.B. (2013). A contextual, flexibility-based model of the HR-firm performance relationship. Cornell University, Ithaca, New York, USA. Management Decision Vol. 50 No. 5, 2012 pp. 909-924. Emerald Group Publishing Limited.

Whitener, E.M. (2001). Do "High commitment" human resources practices affect employee commitment? A crosslevel analysis using hierarchical linier modelling. Journal of Management, 27: 515-535.

Valverde M., Tregaskis O., \& Brewster C. (2000). Labor flexibility \& Firm Performance. International Advances in Economic Research. November 2000, Volume 6, Issue 4, pp 649-661.

Wright, P. and Snell, S. (1998). Toward a unifying framework for exploring fit and flexibility in strategic human resource management. Academy of Management Review, Vol. 23 No. 4, pp. 756-72.

Yamin, S. dan Kurniawan, H. (2011). Generasi baru mengolah data penelitian dengan Partial Least Square Path Modelling: Aplikasi dengan software XLSTAT, Smart PLS, dan Visual PLS. Penerbit Salemba Infotek. 